International Journal of Agriculture, Environment and Bioresearch

Vol. 5, No. 01; 2020

ISSN: $2456-8643$

\title{
GROWTH AND YIELD RESPONSES OF MUSKMELON (CUCUMIS MELO L.) TO DIFFERENT PLANTING SEASONS IN ADO-EKITI
}

\author{
Aluko M. ${ }^{1^{*}}$, Ayodele O.J. ${ }^{2}$, and Salami A.E. ${ }^{1}$ \\ ${ }^{1}$ Department of Crop, Horticulture and Landscape Design, Ekiti State University, Ado-Ekiti, Nigeria \\ ${ }^{2}$ Department of Soil Resources and Environmental Management, Ekiti State University, Ado-Ekiti, Nigeria \\ https://doi.org/10.35410/IJAEB.2020.5462
}

\begin{abstract}
A field experiment was conducted to determine the effects of planting season on the growth and yield of muskmelon (Cucumis melo L) at the Teaching and Research Farm of the Ekiti State University, Ado-Ekiti, Nigeria during the 2017 and 2018 cropping seasons. The treatments consisted of three planting seasons; viz dry (January), early (May) and late (September) planting seasons. The experiment was laid out in a randomized complete block design, replicated three times. Data were collected on growth, yield and yield components of muskmelon and were subjected to analysis of variance and treatment means separated using Duncan Multiple Range Test at $5 \%$ probability. Muskmelon sowed in May gave 71.33 mean number of leaves and $133.83 \mathrm{~cm} 2$ leaf area at 10 WAS which was significantly $(\mathrm{P}<0.05)$ higher than 63.67 and 90.78 $\mathrm{cm} 2$ for January and 43.33 and $97.78 \mathrm{~cm} 2$ for September. Sowing in September gave 11300.00 number of fruits per hectare and $10.70 \mathrm{t}$ ha-1 fruit weight which was higher than 10697.30 and $10.63 \mathrm{t}$ ha-1 for May and 10466.70 and $8.09 \mathrm{t}$ ha-1 for January. Although sowing in September gave higher number of fruits and fruit yield, planting in May gave higher marketable yield (15.58 $\mathrm{cm}$ fruit length, $11.90 \mathrm{~cm}$ fruit diameter and $0.92 \mathrm{~kg}$ fruit weight). Planting muskmelon in September produced fruits with $3.59 \%$ total soluble sugar (TSS) which were sweeter than fruits produced by January (3.33 \% TSS) and May (3.03 \% TSS) sowing dates. Therefore it is advisable to plant muskmelon during the rainy season except if and when adequate irrigation is made available during dry season.
\end{abstract}

Keywords: Muskmelon, sowing, season, growth, yield.

\section{INTRODUCTION}

Muskmelon (Cucumis melo L) a member of the family Cucurbitaceae (Maynard et al., 2001) is mostly referred to as cantaloupe in United States of America. The genera CucumisL.is one of the widely cultivated cucurbitaceaethat consists of two sub-species which areC. melo ssp. melo and C. melo ssp. agrestis(Jeffrey, 1980; Kirkbride, 1993). According to Pitrat et al. (2000)Cucumis melo ssp. melo comprises of 11 types of melons one of which is muskmelon (reticulatus). Others include cantalupensis (cantaloupe), adana, chandalak, ameri, inodorus (winter melon), flexuosus (snakemelon), chate, tibish, dudaim and chito (mango melon, garden melon). It is widely cultivated in the tropical, sub-tropical and temperate region of the world. China is the largest muskmelon producer, followed by Turkey (FAO, 2014). Despite Africa being the origin of muskmelon (Paris and Janick, 2008), production is slowing increasing as most countries (e.g 
Sudan and Kenya) produce mainly for exportation to Europe (Vihji, 2016). In Nigeria, there is no existing record of muskmelon production.

Muskmelon is a crop grown mainly for its nutritional benefits. The fruits contain 90 percent water which makes it useful to prevent dehydration and reduce constipation. Muskmelon contains folic acid that helps to create healthy foetuses (in pregnant women) and prevent cervical cancer and osteoporosis. The potassium present in it is quite helpful in lowering of blood pressure (Lester and Hodges, 2008). It is a rich source of vitamin C, B-carotene (vitamin A), carbohydrates, sugars, protein and traces of vitamin B6, vitamin $\mathrm{K}$, niacin, vitamin $\mathrm{B} 2$, and vitamin B1.Muskmelon is a good source of food nutrient which improves vision, sooth stomach ulcers, and an immune booster (Kapoor, 2015). Oxykine, an extract of muskmelon has been used to inhibit kidney stones, thereby solving kidney problems. The roots have emetic and purgative properties (Hazara et al., 2010).

Sowing dates are effective in extending the production seasons of acceptable yields with good internal quality of melon (Cucumis melo L.) cultivars (Dufault et al., 2006). Studies on two cantaloupe hybrids ("Rafegal (c-8)" and "Galia") in summer at Assiut, Egypt adjudged mid-year (July) planting as the best date of planting (Refai te al., 2008). The work of Rodriguez et al. (2007) on Galia variety indicated that muskmelon planted between August and December has been produce fruit yield which were three times higher than those muskmelon planted between October and Februaryby the studies of Shaw et al. (2001) at the same location. Cultivation of cucurbitaceae in Nigeria is mainly during the raining season either as early or late planting. Early plantings are observed in April/May, while late planting is in late August /September. Planting of Pumpkin (Cucurbita pepo Linn.) at the onset of rainy season will bring about optimal yield and food value of pumpkin at any location in the rainforest zone of Nigeria (Oloyede and Adebooye, 2013). The observation of Ogbonnaand Obi (2007) onegusi melon (Colocynthis citrullus L.) at the derived savannah region of Nigeria showed that plantingshould be at the onset of rainy season (that is, March) while Nwofia et al. (2015) reported significant increases in fruit yield of cucumber in the early planting season under rain-fed condition. Planting of watermelon at the onset of the rainy season and towards the end of the rainy season has been recommended for farmers in Nigeria (Adekunle et al., 2005).

Ekiti State with the capital at Ado-Ekiti is in the rain forest zone of Nigeria with about $70 \%$ of her population engaging in farming (NAERLS and NPAFS, 2010). Production of cucurbitaceae such as watermelon (Ajewole, 2010), cucumber (Awe et al., 2016), pumpkin (Arowosegbe et al., 2015) and egusi melon (Ayodele and Shittu, 2013) has been reported in Ekiti State where production is mostly done under rain-fed condition. Although, it was reported that these crops can be planted at any time of the year, provided there is adequate irrigation (Awe et al., 2016), but rainy season planting gives the highest yield. Although, in Nigeria few studies has been conducted on the influence of planting dates on muskmelon, however, there is paucity of published statistical data and research information on the effects of sowing dates on muskmelon in South western Nigeria, especially Ekiti State. To this end, this study is aimed at evaluating the effects of sowing dates on the growth and yield of muskmelon.

\section{MATERIALS AND METHODS}


Vol. 5, No. 01; 2020

ISSN: $2456-8643$

\subsection{Experimental Site:}

The experiment was conducted on the Crop, Horticulture and Landscape Department experimental field of the Teaching and Research Farm of the Ekiti State University, Ado-Ekiti, Nigeria. Ado-Ekiti is located at 7o 31 ' $\mathrm{N}$ and 5o 13' $\mathrm{E}$ and about $540 \mathrm{~m}$ elevation. Ado-Ekiti is classified as a tropical rain forest zone with the mean annual rainfall of $1334 \mathrm{~mm}$ with two main seasons (rain and dry). The rainy season is between March and October with about two week break in August and November to February are referred to as the dry period. The rainfall and temperature pattern for 2017 and 2018 was shown in Figure 1.

\subsection{Experimental Treatments and Design}

The treatments consisted of three planting seasons: January (dry season), May (early rainy season) and September (late rainy season). The experiment was laid out in a randomized complete block design in three replicates.

\subsection{Experimental Procedures}

The experimental site was cleared of bushes, ploughed, and harrowed and later laid out according to experimental design. Block of $4 \times 4 \mathrm{~m}$ plot in three replications were set out. Surface application of poultry manure at $20 \mathrm{t}$ ha-1 at $3-5 \mathrm{~cm}$ soil depth was carried out two weeks before planting. Two seeds of muskmelon were sowper stand at a spacing of $1 \times 1 \mathrm{~m}$ which was later thinned to one seedling per stand, two weeks after sowing (WAS). Basal application of $50 \mathrm{~kg} \mathrm{~N}$ ha-1 NPK 15:15:15 was done at 4 WAS. Hand weeding was done fortnightly and other crop management practices, such as spraying with insecticide. Netting of treatment plots was done using insecticide-treated nets to prevent the fruits from pest infestation.

\subsection{Data Collection Methods}

\subsubsection{Growth parameters}

Data on growth parameters were collected weekly from 5 to 10 WAS. The number of leaves and number of branches per plant were determined from the three randomly selected plants per each treatment plot. The average was recorded as the number of leaves per plant and the number of branches per plant for each planting season. The length and breadth of leaf were measured with a measuring tape from three randomly selected leaves per plant from the three selected plants per treatment plot. The average was calculated and used as the leaf length and breadth. The leaf area was determined based on Panta and NeSmith (1995) model for estimating muskmelon leaf area (Leaf area $=3.30+0.63$ (W2) where $\mathrm{W}$ is leaf width). The vine lengths $(\mathrm{cm})$ both of the stem and branches were measure with measuring tape from the point of spouting from soil to the tip of the stem (stem) and from the node point to the branch tip (branches). This was done on the three randomly selected plants per treatment plot and the average was taken as the stem and branch vine length respectively. 


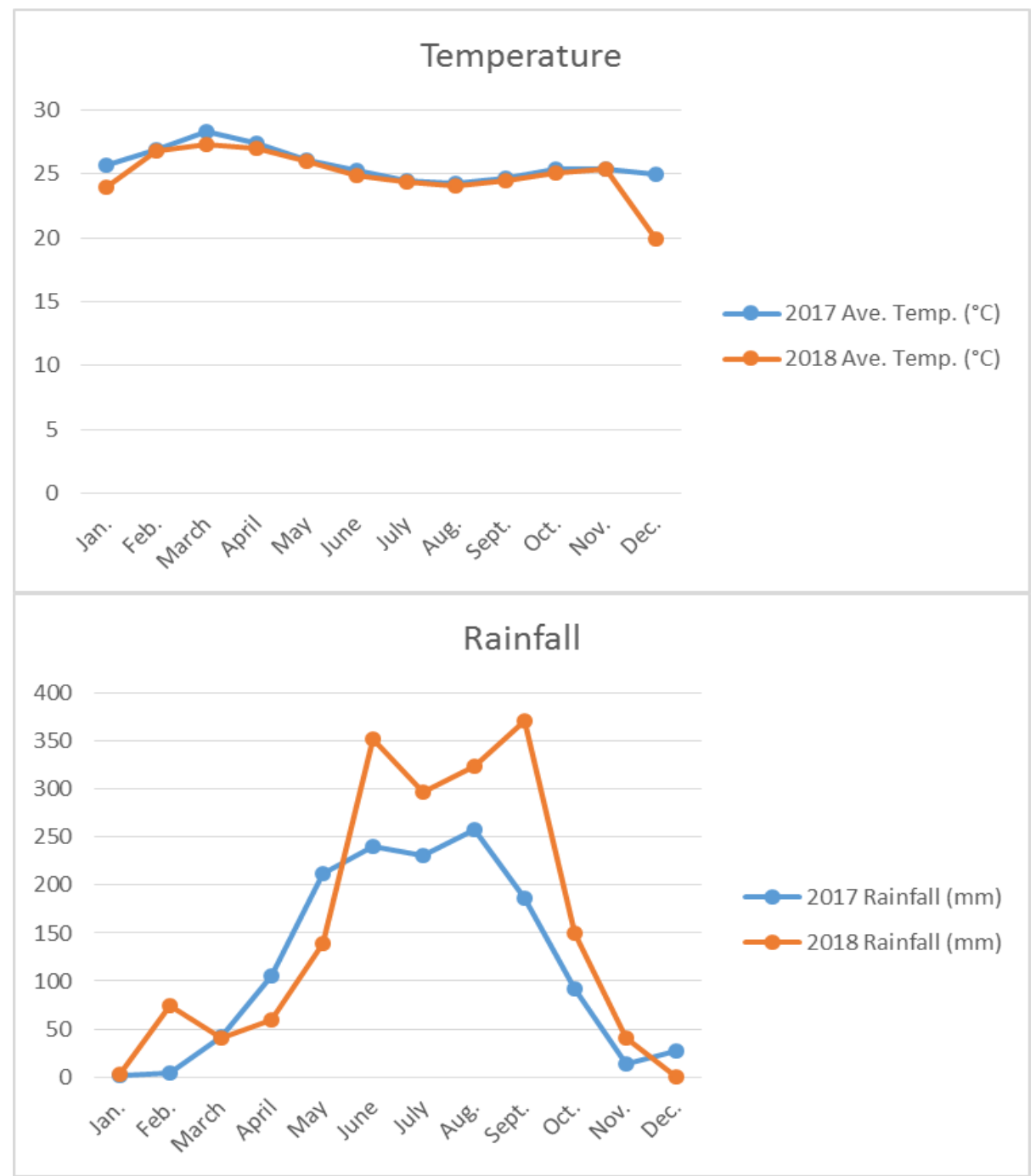

Fig. 1. Rainfall and temperature pattern of the experimental site for 2017 and 2018.

\subsubsection{Flowering of Muskmelon}

The number of flowers per plant was counted from the three randomly selected plants per treatment plot and the average recorded as the number of flowers per plant. The first day of flowering was noted and taken as the day to first flowering for each planting season, while the day when about $50 \%$ of the plants per treatment plot flowered was recorded as the day to $50 \%$ flowering for each planting season.

\subsubsection{Yield and Yield Components}

Yield data were collected at physiological maturity. The number of fruits harvested per plant was determined from the three randomly selected plants per each treatment plot and the average recorded as the number of fruits per plant. The total number of fruits harvested per plot was 
Vol. 5, No. 01; 2020

ISSN: $2456-8643$

calculated and converted to the number of fruits per hectare, which was taken as the fruit yield of muskmelon per planting season. Five fruits were randomly selected per each treatment plot and weighed. The fruit weight was calculated and converted to total fruit weight per hectare. The fruits selected were measured for fruit length and diameter $(\mathrm{cm})$ with a measuring tape and Venn Caliper respectively. The average was recorded as the fruit length and diameter for each planting season. Selected fruits were diagonally dissected and the pulp length measured with Venn Caliper. The number of seeds and seed weight per fruit were determined and weigh on weighing balance and recorded.

\subsubsection{Fruit Quality}

Theproximate analysis of randomly selected harvested fruits was done to determine the carbohydrate, protein, crude fibre, fruit fat, and ash content using AOCA (2009) methods. The chemical analyses of the selected fruits were carried out through the analytical method (spectrometry) (Greenberg et al., 1985) and total soluble sugar was determined quantitatively by Lane and Eynon titration method of approach.

\subsection{Data Analysis}

The data collected were subjected to generalize linear model of SAS for ANOVA and treatment means were separated using Duncan's Multiple Range Test at 0.05 level of probability.

\section{RESULTS AND DISCUSSION}

Experimental site Table 1 shows the results of the physical and chemical properties of soil in the study site before planting. The soil of the study site was $2.52 \%$ organic matter, $0.7 \mathrm{mg} \mathrm{g}-1$ total $\mathrm{N}, 18.54 \mathrm{mg} \mathrm{kg}-1$ available $\mathrm{P}, 0.28 \mathrm{mg} \mathrm{kg}-1$ exchangeale $\mathrm{K}$ with $\mathrm{pH}$ of 5.32 . The soil is Alfisol(Soil Survey Staff 2010), with top sandy-loam to clay texture (Fasina et al., 2005). 
Table 1: Physical and chemical properties of soil used before the commencement of the experiment

\begin{tabular}{|c|c|c|c|c|c|c|c|c|}
\hline \multicolumn{9}{|c|}{ Chemical properties } \\
\hline \multirow[t]{2}{*}{$\mathrm{pH}$} & $\mathrm{OC}$ & $\mathrm{OM}$ & $\mathrm{TN}$ & $\mathrm{Ca}$ & $\mathrm{K}$ & $\mathrm{Na}$ & $\mathrm{Mg}$ & Av.P \\
\hline & \multicolumn{2}{|c|}{-------\% ----- } & $\mathrm{mg} \mathrm{g}^{-1}$ & \multicolumn{5}{|c|}{ 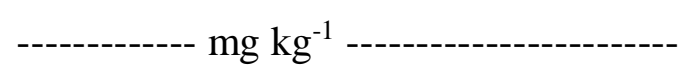 } \\
\hline 5.32 & 1.46 & 2.52 & 0.7 & 5.82 & 0.28 & 0.08 & 0.86 & 18.54 \\
\hline \multicolumn{9}{|c|}{ Physical properties } \\
\hline Sand & Silt & Clay & Texture & & & & & \\
\hline 82.12 & 10.00 & 7.88 & SL & & & & & \\
\hline
\end{tabular}

pH: alkalinity/acidity; OC: Organic carbon; OM: Organic matter; TN: Total nitrogen; Ca: Calcium; K: Potassium; Na: Sodium; Mg: Magnesium; Av.P: Available phosphorus; SL: Sandy loam

\subsection{Effects of planting seasons on muskmelon growth parameters}

The effects of planting season on some growth parameters of muskmelon were shown in Figure 1. Planting of muskmelon in May gave 71.33 mean number of leaves at 10 WAP which was significantly $(\mathrm{P}<0.05)$ higher than 63.67 for January and 43.33 for September planting. Number of leaves increased with plant age.The number of leaves produced in May planting at 10 WAS was 6 and $17 \%$ significantly higher than number of leaves produced in January and September planting. The number of leaves of muskmelon planted in January and September were not significantly different till the tenth week after planting. The number of leaves produced by muskmelon were higher in September planting than January planting at the early stage of growth but reverse was the case at later stage of growth with no significant different between them. The number of leaves of muskmelon planted in January increased gradually until the 7 WAS due to the onset of rainfall while those planted in September began to decline as the rainfall decreased. Early planting of muskmelon at Ado-Ekiti at the onset of rainy season (May) showeda significant increase in leaf area with the highest value at 9 WAS $(133.83 \mathrm{~cm} 2)$. This indicated that muskmelon planted in May produced leaf area that was 13 and $11 \%$ higher than leaf area for January and September respectively. The longest step vine length of $114.33 \mathrm{~cm}$ was obtained in muskmelon planted in May at 10 WAS and was significantly $(\mathrm{P}<0.05)$ higher than $82.28 \mathrm{~cm}$ for January and $106.00 \mathrm{~cm}$ for September. The length of muskmelon branchfor May was $126.62 \mathrm{~cm}$ that was significantly higher than $80.96 \mathrm{~cm}$ for January and 77.33 for September. Planting muskmelon in January and September did not differ significantly on branch length. There was a 
significant increase in the number of branches per plant from 7 to 10 WAS. Water availability may be responsible for better growth performance in muskmelon planted in May. The report of Oloyede and Adebooye (2013) on the production of pumpkin in the rain-forest zone of Nigeria shows that planting at the beginning of rainy season gave better growth and yield which was collaborated by Nwofia et al. (2015) on cucumber with early planting in rain-fed condition. Awe et al. (2016)drip irrigation studies on cucumber production report twice weekly drip irrigation for optimum growth and yield while early report by Kusvuran (2012) on muskmelon (Cucumis melo L.) indicated that exposing melon to only 12 days water stress was enough to affect its growth. This indicated the importance of water to the growth of cucurbit. The results obtained in this study showed planting of muskmelon during the rainy season perform better than those planted during the dry season.

\subsection{Effects of planting seasons on flowering of muskmelon}

The effects of planting seasons on flowering of muskmelon was showed in Figure 2. The first evidence of flowering was observed 30 days after sowing (DAS) in muskmelon planted in May followed by 32 DAS for muskmelon planted in January and 41 DAS for muskmelon planted in September. It took 46 DAS for $50 \%$ of muskmelon planted in September to produced flowers which was significantly higher than 34 DAS for muskmelon planted in May and 38 DAS for 50 $\%$ muskmelon planted in January. This delay in flowering may be to water stress. Early flowering of muskmelon planted in May resulted in early fruit maturity thereby reducing the period of the production. The highest average number of flowers per plantof 7.17 was observed from muskmelon planted in September at 7 WASbefore declining which was significantly higher than 4.33 from muskmelon planted in January and 4.00 for May. Muskmelon planted in January and May gave their highest number of flowers of 6.83 and 6.00 at 9 WASbefore declining. Muskmelon planted in May produced 5.83 number of flowers at 10 WAS which was significantly higher than 2.17 for January and 0.17 for September. But most of these flowers were aborted as a result of higher volume of rainfall which invariably reduced the number of fruits produced.

\subsection{Effects of planting seasons onyield and yield components of muskmelon}

Table 2 showed the effects of planting seasons of muskmelon on the yield and yield components of muskmelon. The muskmelon planted in September produced 11300.00 number of fruits per hectare which was higher than 10466.70 for January and 10697.30 for May planting but not significantly different $(\mathrm{P}>0.05)$. Muskmelon planted in May gave higher fruit length $(15.58 \mathrm{~cm})$ and diameter $(11.90 \mathrm{~cm})$ with an average fruit weight of $0.92 \mathrm{~kg}$ which was 3 and $2 \%$ higher than $0.78 \mathrm{~kg}$ for January and $0.89 \mathrm{~kg}$ for September but did not differed significantly. Muskmelon planted in September produced the highest fruit yield per hectare of $10.70 \mathrm{t}$ ha-1 which was not significantly different from $10.63 \mathrm{t}$ ha- 1 for May and $8.09 \mathrm{t}$ ha-1 for January. The dates of planting had no significant effects on the number of seeds per fruit and the fruit pulp length. Seed weight of $2.48 \mathrm{~g}$ for muskmelon planted in January was significantly higher than1.69 gfor May and 1.73gfor September planting. The fruits of muskmelon planted in May produced fruits with the highest 
International Journal of Agriculture, Environment and Bioresearch

Vol. 5, No. 01; 2020

ISSN: $2456-8643$

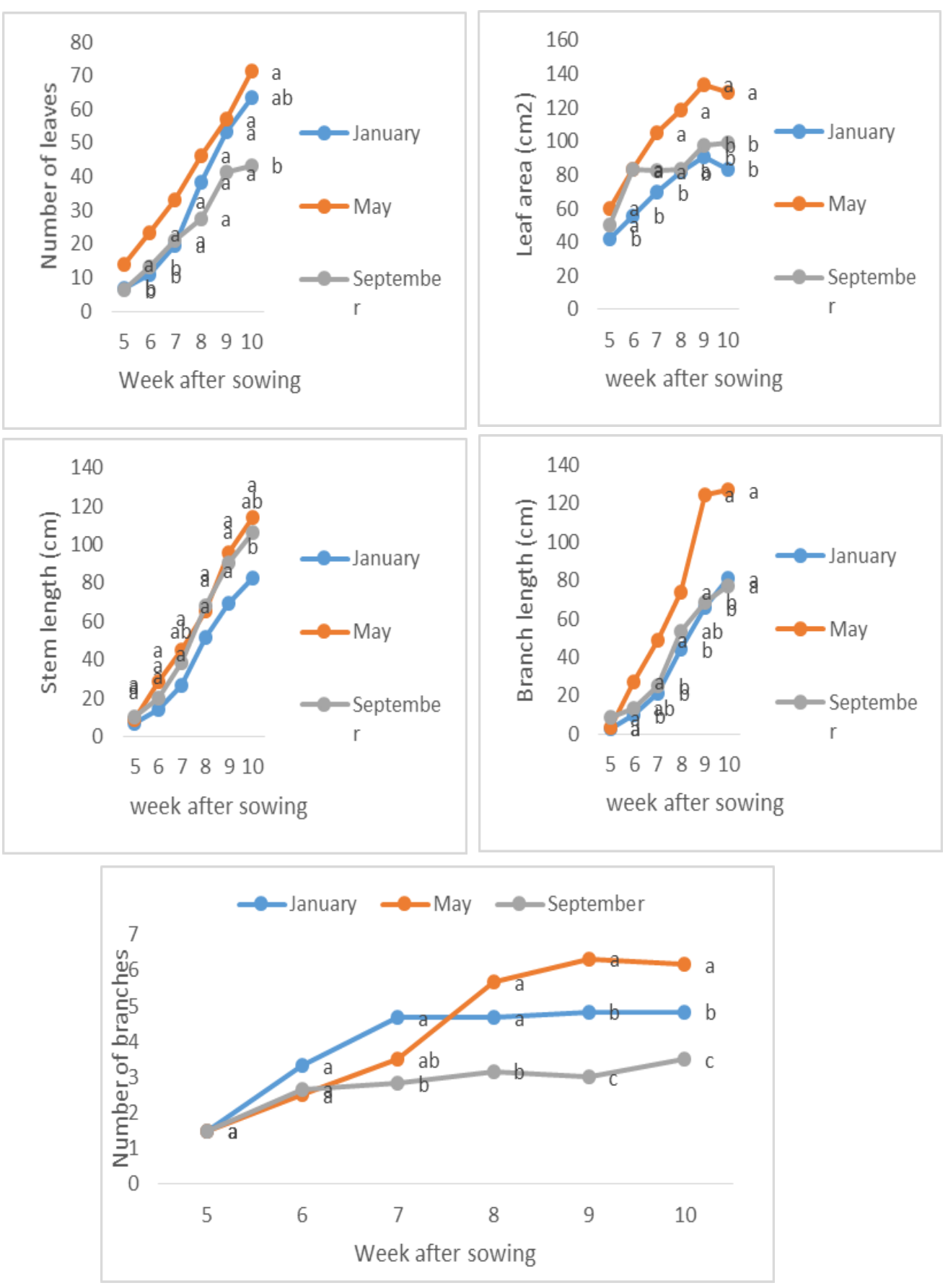

Fig 2. Effects of planting seasons on the growth of muskmelon in Ado-Ekiti 

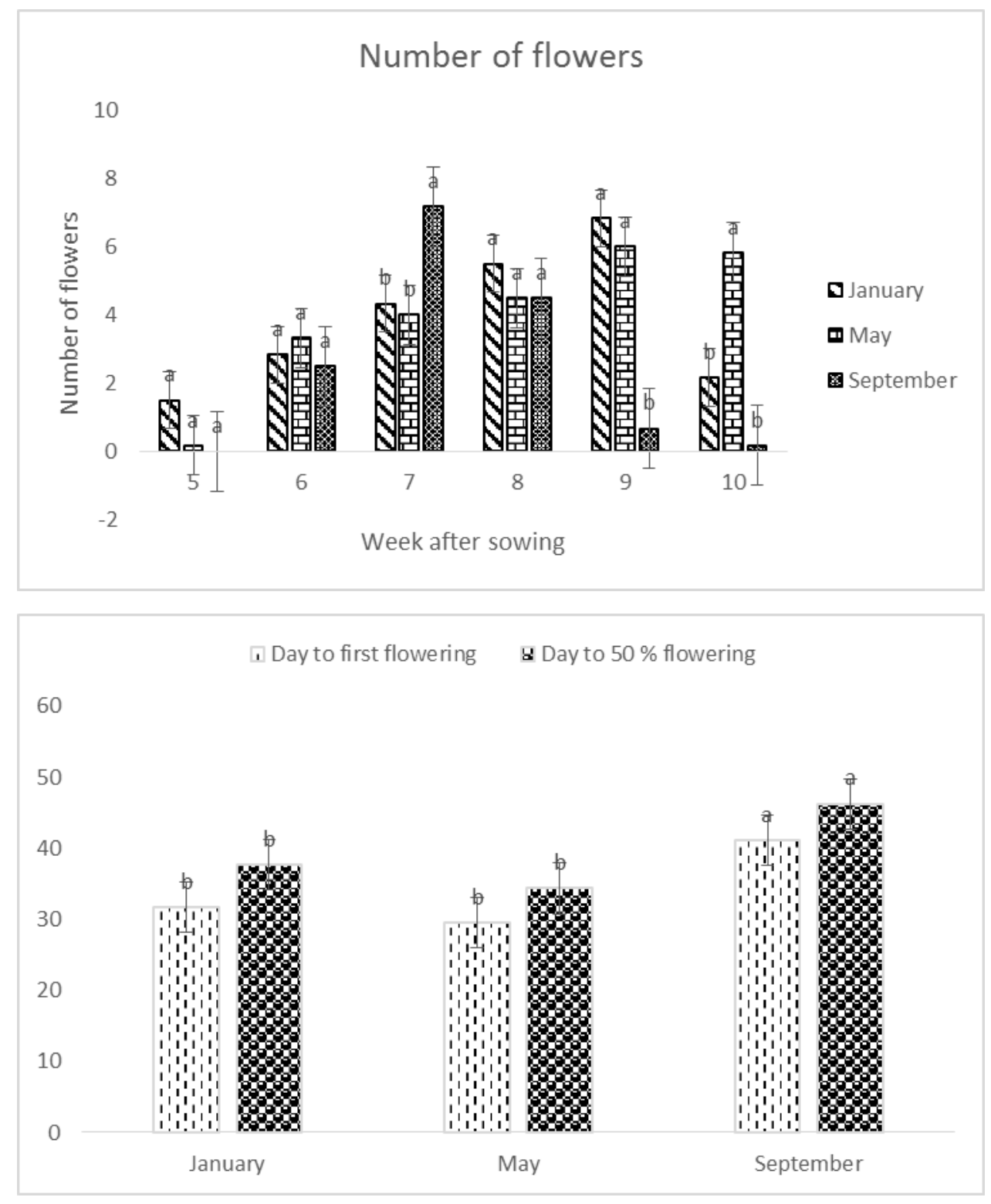

Fig 3. Effects of planting seasons on flowering of muskmelon in Ado-Ekiti

Number of seeds but these seeds were lighter compared with the seeds of muskmelon fruits planted in January and September.

Rodriguez et al. (2007) reported a linear increase in the marketable yield of Galia-type muskmelon (Cucumis melo cv. Gal-152). This increase in yield was three times higher in muskmelon plantbetween August and December compared to the early work of Shaw et al. (2001) at the same location that was conducted between October and February. The results 
obtained from this study indicated that muskmelon planted in September gave the highest fruit yield per hectare but those planted in May gave the higher marketable yields as it had the highest mean fruit size which was in agreement with the reports of Refia et al. (2008) andRodriguez et al. (2007). The reports of Awe et al. (2016) on cucumber and Ayodele and Shittu (2013) on egusi melon at Ado-Ekiti showed that cucurbits responded positively to water availability, suggesting indispensability of water in crop production. Awe et al. (2016) reported drip irrigation scheduling twice weekly gave optimum yield in cucumber production. The reports of Leskovar et al. (2001), Rouphael et al. (2008), Kusvuran (2012) and Özbahçeet al. (2014) indicated that melon responed to water positively as water stress resulted in lower fruit yield production. Increase in water stress resulted into linear decrease in marketable yield of muskmelon(Rouphael et al., 2008). Water greatly influences the yield of vegetables including muskmelon (Mishra et al., 2017). Planting muskmelon in January (dry season in Ado-Ekiti) led to decrease in fruit yield while muskmelon planted in September (late planting in Ado-Ekiti) resulted in higher fruit yield per hectare than those planted in May ( onset of rain). This indicated that muskmelon planted in September had access to sufficient water needed for growth and fruiting before the drying season set in by November. These higher fruiting in September may be as a result of lower rainfall that favour the production of more flowers as against dropping of flowers due to the heavy down pour of rain during the rainy season. Muskmelon planted in May produced fruits with the higher average size and this is in agreement with the report of Qudeimat et al. (2004)who observed a significant increase in fruit weight with increased water supply.

Table 2. Effects of dates of planting onfruityield and yield components of muskmelon

\begin{tabular}{|lllllllll|}
\hline $\begin{array}{l}\text { Date of } \\
\text { planting }\end{array}$ & $\begin{array}{l}\text { Number } \\
\text { of fruits } \\
\mathrm{ha}^{-1}\end{array}$ & $\begin{array}{l}\text { Fruit } \\
\text { length } \\
(\mathrm{cm})\end{array}$ & $\begin{array}{l}\text { Fruit } \\
\text { diameter } \\
(\mathrm{cm})\end{array}$ & $\begin{array}{l}\text { Mean } \\
\text { fruit } \\
\text { weight } \\
(\mathrm{kg})\end{array}$ & $\begin{array}{l}\text { Total } \\
\text { fruit } \\
\text { weight } \\
(\mathrm{t} \mathrm{ha})^{-1}\end{array}$ & $\begin{array}{l}\text { Number } \\
\text { of seeds }\end{array}$ & $\begin{array}{l}\text { Fruit } \\
\text { pulp } \\
\text { length } \\
(\mathrm{cm})\end{array}$ & $\begin{array}{l}\text { Seed } \\
\text { weight } \\
(\mathrm{g})\end{array}$ \\
\hline January & $10466.70 \mathrm{a}$ & $13.12 \mathrm{a}$ & $9.76 \mathrm{a}$ & $0.78 \mathrm{a}$ & $8.09 \mathrm{a}$ & $304.00 \mathrm{a}$ & $1.92 \mathrm{a}$ & $2.48 \mathrm{a}$ \\
May & $10697.30 \mathrm{a}$ & $15.58 \mathrm{a}$ & $11.90 \mathrm{a}$ & $0.92 \mathrm{a}$ & $10.63 \mathrm{a}$ & $417.50 \mathrm{a}$ & $2.03 \mathrm{a}$ & $1.69 \mathrm{~b}$ \\
September & $11300.00 \mathrm{a}$ & $14.08 \mathrm{a}$ & $8.95 \mathrm{a}$ & $0.89 \mathrm{a}$ & $10.70 \mathrm{a}$ & $407.33 \mathrm{a}$ & $2.42 \mathrm{a}$ & $1.73 \mathrm{~b}$ \\
\hline
\end{tabular}

Mean values with the same letter(s) on the same column are not significantly different at 5\% probability (DMRT)

\subsection{Effect of planting dates on fruit quality of muskmelon}

Tables 3 and 4 shows the effects of planting seasons on the quality of muskmelon fruits produced. Muskmelon planted in May produced fruits with moisture contents of $90.06 \%$ higher than 89. $93 \%$ for January and $89.40 \%$ for September planting. Planting muskmelon in September produced fruits which were higher in ash content $(0.51 \%)$, protein $(2.14 \%)$, 
carbohydrate $(7.15 \%)$, and total soluble sugar (3.59 \%) than those produced by January and May planting. Muskmelon planted in September produced fruits that gave $0.34 \% \mathrm{~N}, 46.59 \mathrm{mg} \mathrm{kg}-1 \mathrm{P}$ and $208.49 \mathrm{mg} \mathrm{kg}-1 \mathrm{~K}$ which was significantly higher than $0.33 \% \mathrm{~N}, 21.08 \mathrm{mg} \mathrm{kg}-1 \mathrm{P}$ and 27.60 $\mathrm{mg} \mathrm{kg}-1 \mathrm{~K}$ for January and $0.26 \% \mathrm{~N}, 34.24 \mathrm{mg} \mathrm{kg}-1 \mathrm{P}$ and $29.58 \mathrm{mg} \mathrm{kg}-1 \mathrm{~K}$ for May. Muskmelon planted in September produced fruits which were sweeter than those fruits produced by January and May planting and this may be due to higher sugar content and lower moisture content. The higher level of rainfall in May planting may probably be responsible for higher moisture in the fruits produced. Qudeimatet al. (2004) had observed decreases in total soluble solid percent as the amount of water supply increased.

Table 4. Proximate analysis of muskmelon fruits as influenced by planting seasons

\begin{tabular}{|lllllllll|}
\hline $\begin{array}{l}\text { Date of } \\
\text { planting }\end{array}$ & $\begin{array}{l}\text { Moisture } \\
(\%)\end{array}$ & $\begin{array}{l}\text { Ash } \\
(\%)\end{array}$ & $\begin{array}{l}\text { Crude } \\
\text { fibre } \\
(\%)\end{array}$ & $\begin{array}{l}\text { Fat } \\
(\%)\end{array}$ & $\begin{array}{l}\text { Protein } \\
(\%)\end{array}$ & $\begin{array}{l}\text { Carbohydrate } \\
(\%)\end{array}$ & $\begin{array}{l}\text { Nitrogen } \\
(\%)\end{array}$ & $\begin{array}{l}\text { Total } \\
\text { soluble } \\
\text { sugar } \\
(\%)\end{array}$ \\
\hline January & $89.93 \mathrm{a}$ & $0.58 \mathrm{a}$ & $0.36 \mathrm{a}$ & $0.24 \mathrm{a}$ & $2.05 \mathrm{a}$ & $6.85 \mathrm{a}$ & $0.33 \mathrm{a}$ & $3.33 \mathrm{a}$ \\
May & $90.96 \mathrm{a}$ & $0.32 \mathrm{a}$ & $0.32 \mathrm{a}$ & $0.20 \mathrm{a}$ & $1.65 \mathrm{a}$ & $6.60 \mathrm{a}$ & $0.26 \mathrm{a}$ & $3.03 \mathrm{a}$ \\
September & $89.50 \mathrm{a}$ & $0.51 \mathrm{a}$ & $0.23 \mathrm{a}$ & $0.21 \mathrm{a}$ & $2.14 \mathrm{a}$ & $7.51 \mathrm{a}$ & $0.34 \mathrm{a}$ & $3.59 \mathrm{a}$ \\
\hline
\end{tabular}

Table 5. Mineral compositions (mg kg-1) of muskmelon fruits as influenced by planting seasons

\begin{tabular}{|c|c|c|c|c|c|c|c|c|c|c|c|c|}
\hline $\begin{array}{l}\text { Date of } \\
\text { planting }\end{array}$ & $\begin{array}{l}\mathrm{N} \\
(\%)\end{array}$ & $\mathrm{Na}^{*}$ & $\mathrm{Ca}^{*}$ & $\mathrm{~K}^{*}$ & $\mathrm{P}^{*}$ & $\begin{array}{l}\mathrm{Mg} \\
*\end{array}$ & $\mathrm{Zn} *$ & $\mathrm{Fe}^{*}$ & $\begin{array}{l}\mathrm{Mn} \\
*\end{array}$ & $\mathrm{Cu}^{*}$ & $\mathrm{~Pb}^{*}$ & $\mathrm{Ni}^{*}$ \\
\hline \multirow[t]{2}{*}{ January } & 0.33 & 64.7 & 121.9 & 27.60 & 21.08 & 3.05 & 0.25 & 0.16 & 0.15 & 0.01 & 0.00 & ND \\
\hline & $\mathrm{a}$ & $0 \mathrm{a}$ & $0 \mathrm{~b}$ & $\mathrm{~b}$ & $\mathrm{~b}$ & $\mathrm{~b}$ & $\mathrm{a}$ & $\mathrm{a}$ & $\mathrm{a}$ & $\mathrm{a}$ & $1 \mathrm{a}$ & \\
\hline \multirow[t]{2}{*}{ May } & 0.26 & 67.8 & 166.8 & 29.58 & 34.24 & 4.30 & 0.22 & 0.20 & 0.10 & 0.02 & 0.00 & 0.00 \\
\hline & $\mathrm{a}$ & $5 a$ & $2 a$ & $\mathrm{~b}$ & $a b$ & $\mathrm{~b}$ & $\mathrm{a}$ & $\mathrm{a}$ & $\mathrm{a}$ & $\mathrm{a}$ & $2 a$ & 1 \\
\hline \multirow{2}{*}{$\begin{array}{l}\text { Septem } \\
\text { ber }\end{array}$} & 0.34 & 52.3 & 154.6 & 208.4 & 46.59 & 8.81 & 0.16 & 0.15 & 0.05 & 0.04 & 0.00 & ND \\
\hline & $\mathrm{a}$ & $9 b$ & $1 \mathrm{a}$ & $9 a$ & $\mathrm{a}$ & $\mathrm{a}$ & $\mathrm{a}$ & $\mathrm{a}$ & $\mathrm{a}$ & $\mathrm{a}$ & $1 \mathrm{a}$ & \\
\hline
\end{tabular}

\section{CONCLUSION}


The muskmelon growth parameters as affected by planting dates indicated that planting muskmelon in May produced muskmelon plants of 71.33 number of leaves, $129.42 \mathrm{~cm} 2$ leaf area, $114.33 \mathrm{~cm}$ vine length and 6.17 number of branches at 10 WAP which were significantly higher than the growth parameter values for January and September planting. Planting muskmelon during the rainy season produced higher fruit yield and yield components than its dry season counterpart. Planting in September (late rainy season) produced higher total fruit yield (10.70 t ha-1) than planting in May (early rainy season) (10.63 tha-1) but the early rainy season planting (May) produced higher marketable yield $(0.93 \mathrm{~kg}$ fruit weight). Although muskmelon can be planted at all seasons in Ado-Ekiti, rain-fed planting is recommended due to poor irrigation facilities in the community.

\section{REFERENCES}

Adekunle, A., Fatunbi, A. and Chovwen, A. (2005). Growing watermelon commercially in Nigeria: a training manual Ibadan: IITA. Agriculture Nigeria, p. 14. http://homeguides.sfgate.com

Ajewole, O.C. (2015). Income and Factor Analysis of Watermelon Production in Ekiti State, Nigeria Journal of Economics and Sustainable Development, 6(2): 67-72.

AOAC. (2009). Official Methods of Analysis, Association of Official Analytical Chemists, Arlington, VA., USA.

Arowosegbe, S., Oyeyemi, S.D. and Alo, O. (2015). Investigation on the medicinal and nutritional potentials of some vegetables consumed in Ekiti State, Nigeria International Research Journal of Natural Sciences, 3(1): 16-30.

Awe, G.O., Fasina, A.S., Shittu, O.S., Jejelowo, T.A. and Oparemi, A.D. (2016). Effect of Drip Irrigation Frequency and N-Fertilizationon Soil Physical Properties, Yield and Water Use Efficiency of Cucumber (Cucumis sativus L) in Ado Ekiti, Southwestern Nigeria. Journal of Biology, Agriculture and Healthcare, 6(4): 32-46.

Ayodele, O.J. and Shittu, O.S. (2013). Cost-benefit analysis of melon (egusi) seed and seed oil yield responses to phosphorus fertilizer application International Research Journal of Agricultural Science and Soil Science,3(5): 152-155.

Dufault, R.J., Korkmaz, A., Ward, B.K. and Hassel, R. (2006). Planting date and cultivar affect melon quality and productivity. HortScience, 41(7): 1559-1564.

FAO.(2014)http://faostat.fao.org.

Fasina, A.S., Aruleba, J.O., Omolayo, F.O., Omotoso, S.O., Shittu, O.S. and Okusami, T.A. (2005). Properties and classification of five soils formed on granitic parent materials of Humid southwest, Nigeria. Nigerian Journal of Soil Science,15(2): 21-29.

Hazara, P., Chattopadhyay, A., Karmakar, K., Dutta, S. (2010). Modern technology in vegetable production. New India Publishing Agency New Delhi: 190-191. 
Jeffrey, C. (1980). A review of the Cucurbitaceae. Bot J Linn Soc., 81: 233-247.

Kapoor, S. (2015).20 Reasons Why Muskmelon Is Healthy for You. Practo. 2017

Kirkbride, J.H. (1993). Biosystematic monograph of the genus Cucumis (Cucurbitaceae). Parkway Publishers, Boone (NC, USA). 159 pp.

Kusvuran, S. (2012). Effects of drought and salt stresses on growth, stomatal conductance, leaf water and osmotic potentials of melon genotypes (Cucumis melo L.) African Journal of Agricultural Research,7(5): 775-781.

Leskovar, D.I., Ward, J.C., Sprague, R.W. and Meiri, A. (2001). Yield, quality, and water use efficiency of muskmelon are affected by irrigation and transplanting versus direct seeding. HortScience., 26: 286-291.

Lester, G.E. and Hodges, D.M. (2008). Antioxidants associated with fruit senescence and human health: Novel orange-fleshed non-netted honeydew melon genotype comparisons following different seasonal productions and cold storage durations. Postharvest Biology and Technology, 48: 347-354.

Maynard, D.N., Dunlap, A.M. and Sidori, B.J. (2001). Cantaloupe variety evaluation. Scient. Horticult, 8: 16-20.

Mishral, S., Chugh, C., Sharma, A.K. and Sharma, V. (2017). Correlation analysis of musk melon, Cucumis melo genotypes grown under different water regimes in greenhouse. Biosci. Biotech. Res. Comm., 10(1): 22-27.

NAERLS., NPAFS.(2010). Annual Agricultural Performance Survey Report of Nigeria 2010 Wet Season. NAERLS Press. ISBN: 978-978-912-360-5. 153p.

Nwofia, G.E.,Amajuoyi, A.N. andMbah, E.U. (2015). Response of Three Cucumber Varieties (Cucumis sativus L.) to Planting Season and NPK Fertilizer Rates in Lowland Humid Tropics: Sex Expression, Yield and Inter-Relationships between Yield and Associated Traits. International Journal of Agriculture and Forestry,5(1): 30-37.

Ogbonna, P.E. andObi, I.U. (2000). Effect of poultry manure and planting date on the growth and yield of egusi melon (Colocynthis citrullus L.) in the Nsukka plains of southeastern Nigeria. Samaru Journal of Agricultural Research, 16: 63-74.

Oloyede, F.M. and Adebooye, O.C. (2013). Effect of Planting Date on the Yield and Proximate Composition of Pumpkin (Cucurbitapepo Linn. Fruit. British Journal of Applied Science and Technology. 3(1): 174-181.

Özbahçe, A., Tari, A.F., Yücel, S., Okur, O. and Padem, H. (2014). Influence of limited water stress on yield and fruit quality of melon under soil-borne pathogens. Toprak Su Dergisi., 3(1): 70-76. 
Paris, H.S. and Janick, J. (2008). Reflections on linguistics as an aid to taxonomical identification of ancient Mediterranean cucurbits: the Piqqus of the Faqqous Cucurbitaceae 2008, Proceedings of the IXth EUCARPIA meeting on genetics and breeding of Cucurbitaceae (Pitrat M, ed), INRA, Avignon (France), May 21-24th.

Panta, G.R. and NeSmith, D.S. (1995). A model for estimating area of muskmelon leaves. HortScience., 30(3), 624-625.

Pitrat, M., Hanelt, P. and Hammer, K. (2000). Some comments on infraspecific classification of cultivars of melon. Acta Hort, 510: 29-36.

Qudeimat, E.A., Abu-Rayyan, A.M. and Abu-Awwad, A.M.(2014).The effects of plant spacing and irrigation levels on muskmelon fruit yield and quality. Dirasat.,31: 229-238.

Refai, E.F.S., Hosseny, M.H. and Badawy, A.S. (2006). Effect of planting dates on yield and quality of two cantaloupe hybrids under assiut conditions. Ass. Univ. Bull. Environ. Res., 11(2): 13-25.

Rodriguez, J.C., Shaw, N.L. and Cantliffe, D.J. (2007). Influence of plant density on yield and fruit quality of greenhouse-grown Galia Muskmelon. Hort.Tech.,17(4): 580-585.

Rouphael, Y., Cardarelli, M. and Colla, G. (2008). Yield, mineral composition, water relations, and water use efficiency of grafted mini-watermelon plants under deficit irrigation. Hortscience., 43(3): 730-736.

Şengül, N., Yildirim, O., Halloran, N., Çavuşoğlu, S. and Doğan, E. (2014). Yield and Fruit Quality Response of Drip-Irrigated Melon to the Duration of Irrigation Season Toprak Su Dergisi., 3(2): 90-101.

Shaw, N.L., Cantliffe, D.J. and Taylor, B.S.(2001). Hydroponically produced Galia muskmelon: What's the secret? Proc. Fla. State Hort. Soc., 114: 288-293.

Thimmaiah, S.K. (1999). Standard methods of biochemical analysis. Kalyani Publishers, New Delhi, India.

Vidhi, J.(2016). Muskmelon: Origin, Production and Varieties India atBiologyDiscussion.com. 